Pawet Gromek

Main School of Fire Service in Warsaw, Poland

pgromek@sgsp.edu.pl

DOMINIK DURALSKI

Main School of Fire Service in Warsaw, Poland

dduralski@sgsp.edu.pl

ORCID iD: 0000-0003-3397-4445

\title{
TO RESCUE OR NOT TO RESCUE? SOCIAL READINESS FOR EMERGENCY RESPONSE AND DESIGN OF SOCIETAL SAFETY CULTURE
}

\begin{abstract}
Objective: The research is aimed at ways of shaping the culture of societal safety based on factors determining the profile of social readiness to conduct operational activities in the face of natural and technical disasters. Methods: We used elements of the concept of network analysis of Gomez, Probst and Ulrich, as well as the model of safety culture of Cieslarczyk. On this basis, methodologies of network analysis and designing ways to shape the culture are formulated. The network analysis was used to determine the system of factors affecting the social readiness profile and the possibility of influencing individual elements of this system. The adopted design methodology is presented using an algorithm of conduct. Results: The key role of strengthening and building practical experience has been proven. The legitimacy of doing this in close relationship with educational processes is emphasized. In addition, gaps in the network of relevant factors are indicated. Discussion: Specific guidelines for shaping culture of societal safety are included in the catalogues of methods and activities. Moreover, research restrictions are discussed. Areas of further scientific research in the considered context are also indicated.
\end{abstract}

KEYWORDS: rescue, emergency, safety, societal safety, safety culture 


\section{INTRODUCTION}

According to data from EM-DAT International Disaster Database (EM-DAT, 2019), the number of natural disasters around the world has been steadily increasing. For instance, in 2018 alone, humanity was faced with 282 major floods, droughts, extreme weather events, large-scale forest fires, earthquakes, landslides, etc., which generated material losses of USD 107.77 billion (Roser, 2019). Progressive development of industry and international transport of hazardous materials, as well as relatively high terrorist activity are yet another factors emphasizing the importance of societal safety in the 21st century.

Societal safety concerns the protection of the most important utilitarian values. These are human life and health, as well as property and environment to the extent necessary for survival of the population in biological and living-cultural dimensions (Aven et al., 2004; Høyland, 2018; Gromek, 2018b). It is defined as the ability of a society to maintain critical social functions, to protect health and life of representatives of this society, as well as to ensure an existential minimum in stressful situations (e.g. in the face of hazards) (Olsen, Kruke \& Hovden, 2007). Therefore, it falls under such concepts as, among others, rescue, emergency management, risk, vulnerability, immunity or disaster management (Flage et al., 2014; Borel, 2015; Høyland, 2018; Aslam Saja et al., 2019). Its specificity is emphasized by the fact that in the case of any other type of safety, such a strong impact of protected individuals on protected values with which these individuals are directly related (people's impact on their own safety) is not observed.

According to Palen, Hiltz \& Liu (2007), citizens are often the ones who can provide first aid in the event of a natural or technical disaster. By doing this before the arrival of rescue services (fire brigades, emergency medical teams, etc.), they formally begin the first phase of rescue operations. To confirm the above thesis, data from the National Headquarters of the State Fire Service for the years 2010-2018 in Poland show that bystanders in 50-63\% of cases noticed hazards to societal safety and initiated rescue operations. Employees or residents accounted for $36-49 \%$ of this type of situations. In the majority of cases, this was done in the form of an emergency call (KG PSP, 2019). So, while to ensure societal safety, specialist services, inspections, guards and even 
security systems are often referred to (e.g. national rescue and fire-fighting system, emergency notification system '112') (Gromek, 2015), it is usually a citizen (witness, victim, bystander) who activates them to act. This fact highlights their key role in the context under consideration, especially in the era of developing early warning systems for societal safety hazards (World disaster report, 2009).

The notification of an event is only one element of the entire emergency management process (Jingkai, 2012; Madigan, 2018). Here the question arises as to what other types of rescue operations and to what extent specific reactions from witnesses, onlookers or bystanders can be expected. What is more, the need to identify the factors that determine this activity and its degree, as well as to use the acquired knowledge to rationally and more consciously shape commonly desired human behaviours and activities, gain in importance.

Collins (2013), when conducting research on disaster risk reduction, wonders why, under certain circumstances, some people are ready to expose themselves to the danger of losing health or life to help others, while others are not. Collins (2013) indicates that specific human responses can be derived from physical abilities, possessed information, the presence of specialized services on the spot, as well as socio-economic, cultural and psychological factors. They generally fall under the concept of safety culture and the security climate closely related to it (Thomas et al., 2003; Wiegmann et al., 2004; Dollard \& Bakker, 2010; DeJoy, Smith \& Dyal, 2017; Iqbal et al., 2019). Therefore, safety culture seems to be a suitable cognitive background for seeking answers in connection with the aforementioned doubts. This is indicated by research results of Almklov et al. (2018) regarding safety climate (as part of safety culture), as they refer to hazards characteristic of societal safety. What is more, Price (2006) notes that selected cultural factors (including previous experience) and the resulting ability to assess the situation are reflected in human responses in the face of hazards. Collins (2018), summarizing many years of research conducted at the University of Northumbria (United Kingdom), combines self-organization of local community and cultural factors (e.g. a system of meanings, social relations, beliefs) with the resilience of that community and the ability to reduce the risk of natural and technical disasters. At this point the practical value of 
science (in general) should be emphasized. Therefore, the acquired knowledge in the field of culture of societal safety should be used to design activities to increase the potential of the local community in connection with the occurrence of hazards.

The article presents results obtained in the course of implementation of the second stage of research on the social rescue component in Poland. These studies have been conducted by the author since 2017. During the first stage, cognitive foundations for the study of rescue culture (consistently closely related to the culture of societal safety) were developed on the basis of the model of Cieslarczyk's safety culture (Cieślarczyk, 2009), the profile of social readiness to conduct operational activities in the face of societal safety hazards was determined and statistically significant factors determining this profile were identified as well (Gromek, 2018a). The purpose of this research is to formulate ways to shape culture of societal safety based on the results of the first stage of research. It required defining the set of factors determining this profile. For this purpose, an in-depth analysis of data obtained at the first stage of research using elements of the Gomez, Probst and Ulrich network approach was used. The aforementioned system of relations was referred to the most operational circles of the Cieslarczyk safety culture model, in order to formulate ways of shaping the culture of societal safety.

The structure of the article is as follows: Chapter 2 contains information on theoretical assumptions of the safety culture and a summary of the most important results of the first stage of research. Chapter 3 describes the methodology of the second stage of research, paying special attention to network analysis and designing ways to shape the safety culture. Chapter 4 presents the relevant test results and their discussion. In turn, Chapter 5 contains final conclusion, as well as proposals for further scientific research. 


\section{BACKGROUND}

\section{OUTLINE OF THE THEORY OF SAFETY CULTURE}

Haukelid (2008) indicates that the beginnings of the theory of safety culture go back to the 1980s, when the theory and practice of safety of the Norwegian oil industry began to be referred to. Referring to other researchers, the author emphasizes that since then the analysed issue has been constantly gaining importance, significantly affecting the understanding of mechanisms and rational, intentional shaping of the processes responsible for ensuring broadly understood security (Vaughan, 1996; Reason, 1997; Pidgeon, 1998; Cooper, 2000; Cox \& Cheyne, 2000; Hale, 2000; Richter \& Koch, 2004).

Many definitions of safety culture have been formulated. Their common denominator is the discussion of hardly measurable factors, which generally determines how individual, different people behave in the face of different situations, confronted with different conditions and experiencing them in different ways. That is why the safety culture is perceived as an abstract concept derived from individual and group beliefs, feelings and behaviours (Kennedy \& Kirwan, 1998). Neal \& Griffin (2002) indicate that it specifically combines various, relatively independent safety issues (e.g. safety climate, safety knowledge, motivation to comply with safety standards, and safety-friendly behaviour). Referring to Guldenmund's (2000) view, safety culture expresses the overall aspects of organizational culture (as an abstract construct with a broader meaning) - aspects explaining attitudes and behaviours that can positively affect the level of risk (reducing it) or negatively (increasing it). This is even more strongly emphasized by Fang, Chen \& Louisa (2006), who attribute all existing indicators, beliefs and values, corresponding to the organizational culture in the field that is specifically limited to security, to safety culture.

The relative universality of the various concepts that make up the theory of safety culture has caused great interest among researchers. So far, it has been used in safety research concerning, among others, aviation (Fu \& Chan, 2014), petrochemical industry (Gao et al., 2019), road traffic (Timmermans, 2019), rail traffic (Crawford \& Kift, 2018), health protection (Leonard \& O'Donovan, 2018), welfare (Vogus et al., 2016), nutrition (Nyarugwe et al., 2016), ports 
infrastructure (Corrigan, et al., 2018), employment processes and related processes (Vecchio-Sadus \& Griffiths, 2004; Strauch, 2015), nuclear facilities infrastructure (do Nascimento, Andrade \& de Mesquita, 2017), radiological objects (Kasim et al., 2019) or academic laboratory infrastructure (Ayi \& Hon, 2018).

Different definitions and approaches show safety culture from different perspectives, which means that the catalogue of potential elements of this construct is relatively extensive. $\mathrm{He}, \mathrm{Xu} \& \mathrm{Fu}(2012)$ reviewed the literature on the subject (Zohar, 2000; Minhong, 2001; Harvey at al., 2002; Steward, 2002; Dong-ping \& Yang, 2005; Vinodkumar \& Bhasi, 2009; Wang \& Liu, 2012) and on this basis they identified 32 key elements of safety culture - these elements can be universalized to the form presented in Table 1 .

Table 1.

Universal, key elements of safety culture.

\begin{tabular}{|c|c|c|c|}
\hline Number & Key element & Number & Key element \\
\hline 1 & Relative importance of safety & 12 & $\begin{array}{l}\text { Degree of individual's participation } \\
\text { in safety }\end{array}$ \\
\hline 2 & $\begin{array}{l}\text { Preventable extent of deaths } \\
\text { and injuries }\end{array}$ & 13 & Level of safety training needs \\
\hline 3 & $\begin{array}{l}\text { Safety creates economic } \\
\text { benefits }\end{array}$ & 14 & $\begin{array}{l}\text { Degree of the institutions' safety } \\
\text { responsibility }\end{array}$ \\
\hline 4 & $\begin{array}{l}\text { Degree of safety into } \\
\text { organization management }\end{array}$ & 15 & Effects of community safety \\
\hline 5 & $\begin{array}{l}\text { Safety depends mainly on } \\
\text { safety awareness }\end{array}$ & 16 & $\begin{array}{l}\text { Function of safety } \\
\text { managment bodies }\end{array}$ \\
\hline 6 & Responsibility of safety & 17 & Safety council demands \\
\hline 7 & Awareness of safety input & 18 & Formation way of safety system \\
\hline 8 & Role of safety regulations & 19 & Implementation of safety systems \\
\hline 9 & Safety values formation level & 20 & Types of accidents \\
\hline 10 & $\begin{array}{l}\text { Degree of leaders' } \\
\text { responsibility }\end{array}$ & 21 & Types of safety check \\
\hline 11 & $\begin{array}{l}\text { Understanding of the role of } \\
\text { the safety sector }\end{array}$ & 22 & Caring for injured people \\
\hline
\end{tabular}




\begin{tabular}{|c|c|c|c|}
\hline 23 & Amateur safety management & 28 & Safety management of stakeholders \\
\hline 24 & $\begin{array}{l}\text { Treatment of safety } \\
\text { performance }\end{array}$ & 29 & Function of safety organization \\
\hline 25 & Facilities satisfaction & 30 & $\begin{array}{l}\text { Work of safety departments and } \\
\text { institutions }\end{array}$ \\
\hline 26 & $\begin{array}{l}\text { Mastering of Safety } \\
\text { performance }\end{array}$ & 31 & Overall safety expectations \\
\hline 27 & $\begin{array}{l}\text { Safety performance and } \\
\text { human resources }\end{array}$ & 32 & Emergency response capabilities \\
\hline
\end{tabular}

Source: own elaboration based on $\mathrm{He}, \mathrm{Xu} \& \mathrm{Fu}(2012)$.

It cannot be ignored that research on safety culture is conducted on a major scale to a micro scale, which means to give attention mostly to business transactions, industries or local communities. It is worth noting that safety culture is linked to factors such as attitudes, behaviours, norms and values, training and development processes (acquiring knowledge, developing skills and shaping social groups) and personal responsibility. However, all of these factors affect how a human being behaves in given circumstances (Glendon \& Stanton, 2000). This is important from the point of view of a holistic, systemic approach to security (considering security systems as systems of human activities), especially since the culture of safety is being studied within social engineering systems (Shirali, Shekari \& Angali, 2018). Furthermore, the systemic approach itself is implemented into safety research (Wachter \& Yorio, 2014; Hecker \& Domres, 2018; Li \& Zhao, 2019), including safety culture (Goh, Brown \& Spickett, 2010), and vice versa (Reiman \& Rollengahen, 2014).

At this point the possibility of using rich achievements of the theory of safety culture to study it also in relation to human action systems is revealed. This creates unique opportunities to implement right concepts and tools for national security, societal safety, crisis management, civil protection, emergency management, rescue operations etc.

The multitude of ways of interpreting the safety culture together with the corresponding key elements complicates the use of the right theory to solve practical problems. That is why many safety culture models have been formulated over the years, which in a simplified way map the reality and allow its rational exploration, including comparative analyses and structuring of concepts (Shein, 1992; Davies \& Powell, 1992; Geller, 1994; Geller, 1997; 
Cooper, 2000; Grote \& Kunzler, 2000; Neal, Griffith \& Hart, 2000; Maloney \& Smith, 2003; Choudhry, Fang \& Mohamed, 2007).

In the study of safety cuture, embedded in security systems understood as human action systems (social systems), the Cieslarczyk model deserves special attention. Values constitute its core as these are the foundation of the standards of conduct, which are the next layer of the model. Expected attitudes and then behaviours are built on standards. The outermost layer is operations and cooperation - the building blocks of all security systems understood in the perspective of social systems (Cieslarczyk, 2009). Figure 1 depicts the Cieslarczyk model describing structure of safety culture understood in this way. Ideally, all types of safety are equally important. In real life, however, certain layers or types of safety are given more attention, which is confirmed by historical or political determinants, material culture, etc.

Figure 1.

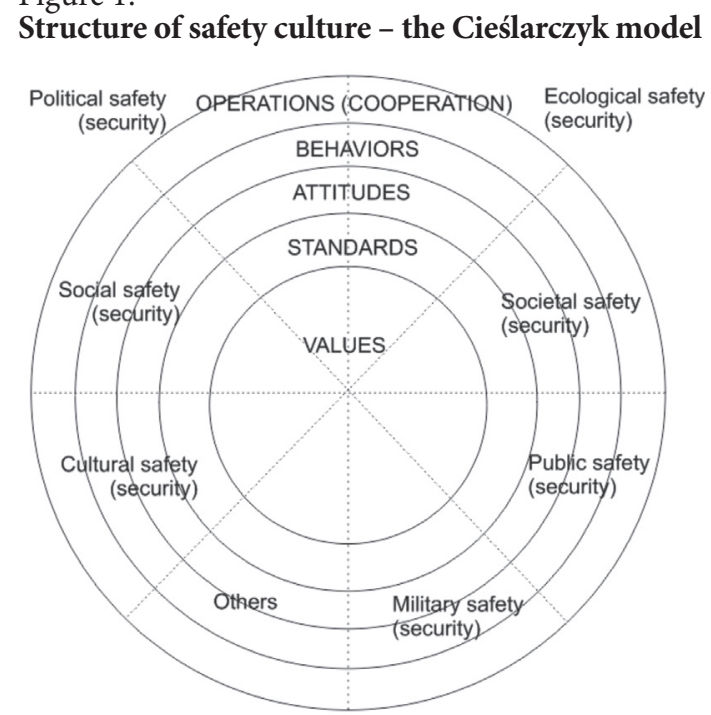

Source: own elaboration based on Cieślarczyk (2009).

The discussed model indicates areas (layers, circles) in which it is worth seeking answers to questions about the activities of entities that are elements of security systems, as well as the reasons why their activities and, possibly, cooperation is as 
it is (Cieslarczyk et al., 2014). At the same time, the model seems to cover all 32 universal, key elements of safety culture. It allows holistic insight into the subject of research, while maintaining their systemic character. Therefore, it is worth to perceive it as a reference point during the study of hardly discernible mechanisms which rule the functioning of security systems and elements of these systems (inter-organizational networks, institutions, social groups, human units and others).

\section{GENERAL RESULTS OF THE FIRST STAGE OF RESEARCH}

The strengths of the Cieslarczyk model determined its usefulness to describe the profile of social readiness to conduct operational activities in the face of societal safety hazards and to identify statistically significant factors determining this profile. The survey using an online questionnaire was conducted between June and December 2017 on a group of 410 randomly selected Polish people, with a 95\% confidence level, 0.5 fraction size and a maximum error of $5 \%$. This ensured statistical representativeness of the relevant results in relation to the population of the entire country (Landau \& Everitt, 2004; Almquist, Ashir \& Brännström, v. 1.0.1; Gromek, 2018a). Statistical analysis was performed using SPSS software.

The questionnaire form of the survey made it possible to determine personal characteristics of the respondents, including their gender, age, marital status, number of children, education, place of residence (number of inhabitants in that place), participation in a rescue organization and previous rescue experience. These traits were considered crucial from the point of view of values and standards located in the very centre of the adopted model of safety culture. Information on respondents is presented in Table 2. 
Table 2.

\section{Information on respondents}

\begin{tabular}{|c|c|c|c|c|c|}
\hline \multirow{2}{*}{ Gender } & Male & $56.8 \%$ & \multirow{3}{*}{ Education } & Primary & $8,5 \%$ \\
\hline & Female & $43.2 \%$ & & Secondary & $62,0 \%$ \\
\hline \multirow{6}{*}{ Age } & $16-20$ & $20 \%$ & & Higher & $29,5 \%$ \\
\hline & $21-30$ & $40 \%$ & \multirow{4}{*}{$\begin{array}{c}\text { Place of residence } \\
\text { (number of residents) }\end{array}$} & $\begin{array}{l}\text { Up to } 1 \text { thou- } \\
\text { sand }\end{array}$ & $16 \%$ \\
\hline & $31-40$ & $19 \%$ & & 1 K. - $50 \mathrm{~K}$. & $33 \%$ \\
\hline & $41-50$ & $12 \%$ & & $50 \mathrm{~K} .-500 \mathrm{~K}$. & $32 \%$ \\
\hline & $51-60$ & $6 \%$ & & Above $500 \mathrm{~K}$. & $19 \%$ \\
\hline & Above 60 & $3 \%$ & \multirow{2}{*}{$\begin{array}{c}\text { Member of a rescue } \\
\text { organization }\end{array}$} & Yes & $3,9 \%$ \\
\hline \multirow{2}{*}{$\begin{array}{c}\text { Marital } \\
\text { status }\end{array}$} & Married & $61,2 \%$ & & No & $96,1 \%$ \\
\hline & Single & $38,8 \%$ & \multirow{3}{*}{$\begin{array}{l}\text { Previous rescue expe- } \\
\text { rience }\end{array}$} & Yes & $28,5 \%$ \\
\hline \multirow{4}{*}{$\begin{array}{l}\text { No. of } \\
\text { children }\end{array}$} & None & $53 \%$ & & \multirow[t]{2}{*}{ No } & \multirow[t]{2}{*}{$71,5 \%$} \\
\hline & One & $23 \%$ & & & \\
\hline & Two & $18 \%$ & & & \\
\hline & $\begin{array}{c}\text { Three or } \\
\text { more }\end{array}$ & $6 \%$ & & & \\
\hline
\end{tabular}

Source: own elaboration based on Gromek (2018a).

Fundamental questions were built on the basis of two external circles of the Cieslarczyk model regarding successive behaviours and operations/cooperation, because these are the most visible manifestations of the rescue culture. The questions concerned whether a given respondent:

1. undertakes rescue operations in the case of fire, technical hazards, release of a dangerous chemical substance, hazard to natural environment, the need to provide first aid only, an accident in the mountains, burying in a trench or an underground facility, hazards on water, hazards in rail transport, exposure to radioactive materials, hazards in air transport and floods (in relation to the model circle labelled "Behaviours"),

2. undertakes specific rescue actions: makes an emergency call, analyses secondary hazards, secures the place of the incident, provides first aid, 
evacuates injured persons and alerts other people in the danger zone (in relation to the model circle labelled "Attitudes"),

3. carries out the instructions of rescue entities: volunteer firefighters, specialist rescue services (e.g. water rescue, mountain rescue), policemen, municipal guards, professional firefighters, authorities or other representatives of public administration, as well as other citizens (in relation to the circle model labelled "Operations (Cooperation)").

The answers were given on a four-point scale: "Sturdily not", "Rather not", "Rather yes", "Sturdily yes" (for the first two questions) or "Yes", "No" and "I don't know" (for the third question).

In the obtained research results, the percentage distribution of the number of respondents expressing the degree of readiness to undertake rescue operations in various circumstances is noteworthy. It shows the profile of social readiness to conduct operational activities in the face of societal safety hazards. It is presented in Figure 2.

Generally, it was confirmed that a higher degree of readiness corresponds to more known threats, including the so-called "everyday threats" and not requiring the use of specialist equipment (fire, transport hazards and those associated with first aid). However, the inverse relationship characterizes mass hazards associated with hardly predictable consequences and the required, usually inaccessible, equipment and personal protective equipment (chemical hazards, radiological hazards, etc.).

Paying attention to specific rescue operations, the majority of respondents indicated making an emergency call, as well as alarming people within the reach of the danger zone. At a comparable level, albeit clearly lower than previous two activities, there were indicated the taking the injured person out of the danger zone, providing first aid, securing the incident site and checking the zone for additional/secondary threats. It is worth noting that professional fire brigades and specialized rescue entities were considered to enjoy the highest respect of citizens. The worst in this respect were volunteer fire brigades, municipal guards and municipal services (Gromek, 2018a).

In addition, the preliminary analysis of the research results allowed to identify relationships between individual factors affecting social readiness in 
Figure 2.

Profile of social readiness to conduct operational activities in the face of universal safety threats

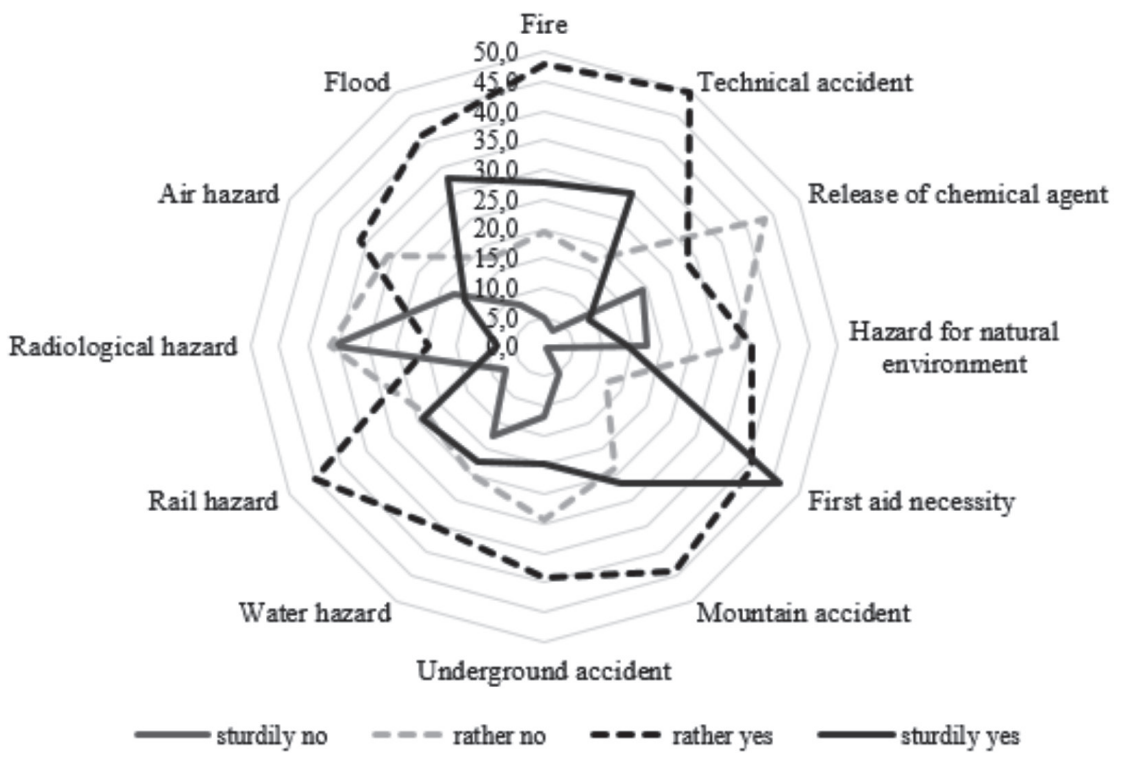

Source: own elaboration based on Gromek (2018a).

the considered circumstances. Statistically significant correlations were noted for the following factors (Gromek, 2018a):

\section{- as positive correlations:}

1. age - fire, hazards in rail transport, hazards in air transport, flood, analysis of secondary hazards, securing the place of incident, taking the injured person out of the danger zone, warning other people;

2. gender - fire, underground accident, hazards on water, hazards in rail transport;

3. status - fire, securing the place of incident, providing first aid, taking the injured person out of the danger zone;

4. number of children - fire, hazards in rail transport, hazards in air transport, securing the place of incident, taking the injured person out of the danger zone, warning other people,

5. previous rescue experience - fire, technical hazards, release of a dangerous chemical substance, hazards to the natural environment, necessity 
to provide first aid, accident in the mountains, underground accident, hazards on water, hazards in rail transport, radiological hazards, hazards in air transport, flood, secondary risk analysis, securing the place of incident, providing first aid, taking the injured person out of the danger zone,

6. education - securing the place of incident;

\section{- as negative correlations:}

1. place of residence - secondary risk analysis.

The results of the research obtained at the first stage show what factors significantly influence the decisions of human beings to undertake rescue operations and the types of these activities. Although they only concern rescue operations, they can be implemented in the field of societal safety. This finds confirmation in the close, even direct semantic relation that occurs between these concepts (Aven et al., 2004; Olsen, Kruke \& Hovden, 2007; Høyland, 2018; Gromek, 2018b). Consequently, rescue can be treated as a type of activity in the field of societal safety - an activity, unlike other types in this scope, undertaken as a matter of urgency, without delay. The preliminary results of research on the culture of rescue can therefore be used as a basis for seeking ways to shape the culture of societal safety. A deductive starting point from perhaps the most demanding type of activity creates the basis for rational design of protection of the most important utilitarian values.

\section{MeThodology}

\section{NETWORK ANALYSIS}

The results obtained at the first stage of the research shed light on to what extent and in relation to what conditions people declare willingness to undertake rescue operations. This knowledge can be used to design activities aimed at raising the level of the culture of societal safety, provided that one learns the set of factors that shape the profile of social readiness. Identified statistically significant correlations suggest that it is a nonlinear, network 
system. This reflects their complexity and shows the possibility of modelling the network layout by affecting selected elements (factors).

The network approach is widely used in scientific exploration related to societal safety (Varda et al., 2004; Hossain \& Kuti, 2010; Wang, Qi \& Wang, 2014; Lassa, 2015; Hossain et al., 2015; Liu at al., 2016; Masys, 2017; Jones \& Faas, 2017; Hamra at al., 2017).

Due to the specifics of the Cieslarczyk model and focus on researching social systems, it is worth using elements of the network approach formulated by Gomez, Probst and Urlich. According to their concept, reality can be seen from the perspective of the entirety (e.g. a system) and relevant parts (consequently elements of this system). Elements can be connected with each other in a diverse, networked-like way, creating more or less organized structures of activities, interactions, entities, etc. In addition, the system interacts with its environment. This means that it interacts and is subject to interaction, reaching different states at different times. By adapting it to the environment, one can control it and/or regulate its impact (Probst \& Gomez, 1989; Urlich \& Probst, 1990; Gomez \& Probst, 1999). The use of elements of this approach will allow not only to learn about the set of factors affecting the profile of social readiness,

Figure 3.

Diagram of network analysis methodology

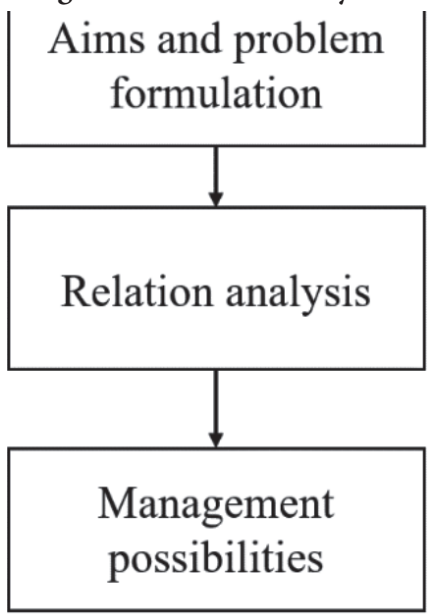

Source: own elaboration based on Ulrich \& Probst (1990). but also to design actions to raise the level of culture of universal safety based on this profile. Referring to the research assumptions, a diagram of the network analysis methodology is presented in Figure 3.

It includes elements of the Gomez, Probst and Urlich network approach, selected and structured in correspondence to the mentioned assumptions. In the first step, aims of the analysis and the problem on which the aims were defined shall be established. Then, the elements of the network (system) should be identified, and, above all, the relationships between 
them shall be indicated. This is the basic stage of building the network - a stage during which, in particular, one should rely on the results of empirical research in order to identify factors influencing the culture of societal safety and determine the relationships between them. As a consequence, these factors should be assessed in terms of which of them can be influenced (manageable factors) and which cannot be influenced (non-manageable factors). Only then it will be possible to specify more specific possibilities of using the network to achieve the assumed aims, approaching proactively towards the identified problem.

\section{DESIGNING WAYS TO SHAPE THE CULTURE OF SOCIETAL SAFETY}

The legitimacy of designing ways to shape a safety culture is confirmed by results of the analysis of literature on the subject. Despite the ever-growing interest of researchers, important deficiencies in this area are apparent (DeJoy, 2005; Hale et al., 2010; Nielsen, 2014).

Raising the level of culture of societal safety should correspond to the results of network analysis of the factors determining it. It will have a real impact on the level of safety in the face of natural and technical disasters, provided they are based on statistically significant data, with real potential to influence the reality.

In the case discussed herein, special attention should be paid to factors influencing rescue operations - the most tangible and socially discernible of all actions aimed at ensuring societal safety. They should constitute a specific foundation in designing ways of shaping the type of culture in question, due to, for instance, a direct connection with the perception of risk by people, their resistance to hazards and societal safety in general (Wolanin, 2017; Collins, 2018).

Figure 4 presents a diagram of the proposed methodology. The first fundamental step is the selection of relationships between factors that are statistically significant and insignificant, and then to focus only on the former. Then, one should choose the guiding factors that can have a real impact in the process of shaping the culture of societal safety in the analysed context. 
Figure 4.

Diagram of the methodology for designing ways to shape a culture of universal safety

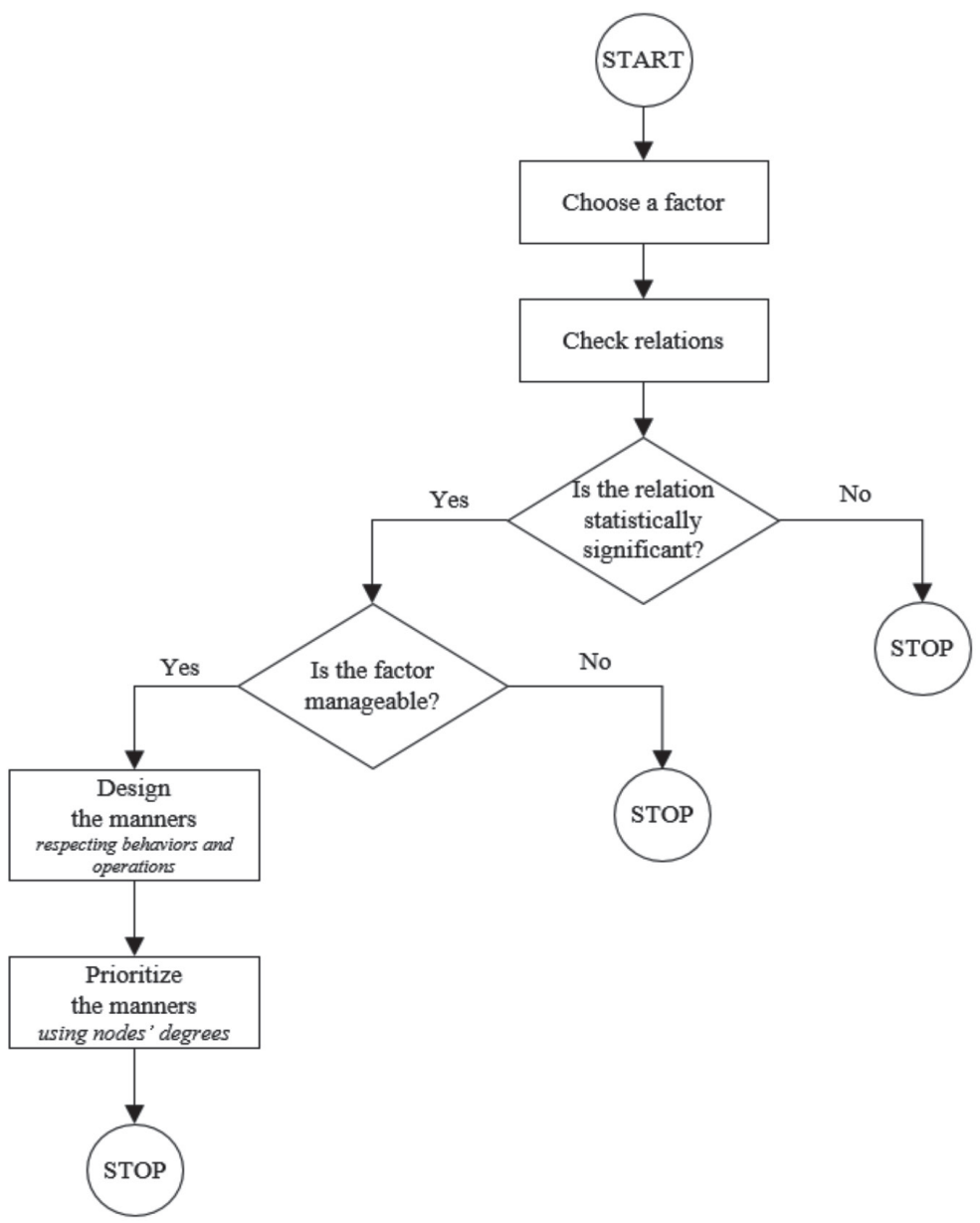

Source: own elaboration.

Designing the right methods is an essential step in this methodology. It should refer to the most specific operational circles of the adopted model of safety culture, namely behaviours and operations. The increase of the implementation value of these methods can be done by assigning implementation priorities based on the potential for impact on social readiness. 


\section{RESULTS AND DISCUSSION}

\section{A NETWORK OF FACTORS INFLUENCING SOCIAL READINESS TO CONDUCT RESCUE OPERATIONS}

The main reason for using network analysis was the need to determine the rationale behind the ways of shaping culture of societal safety. At the first stage of the research, it turned out that statistically significant factors influencing the profile of social readiness are network-related. Therefore, the purpose of using network analysis, in relation to its main reason, was to determine the layout (network) of these factors.

When analysing the relationships between these factors, special attention was paid to personal characteristics, which as elements of the network referring to the central circles of the safety culture model, are crucial in the view of shaping the culture of societal safety (Cieslarczyk, 2009; Schmidt \& Galea, 2013). Consequently, it was examined which types of behaviour and undertaken rescue operations are related to citizens' personal characteristics. The relationships were determined as zero-one based on whether they are statistically significant or not. Figure 5 presents the networked system of connections understood in this way. It includes only statistically significant relationships.

Conducting the network analysis allows to determine the possibilities of using the network to improve the culture of societal safety. Theoretically, each of the examined personal factors can be treated as a manageable one from the perspective of ensuring societal safety (however, from the point of view of shaping the culture of societal safety, this is not so). In other words, a given factor may be subject to influence of an entity providing safety in general, affecting social readiness in the light of various behaviours and activities. This is due to the circumstances corresponding to different phases of societal safety management (not just the response phase). Their joint sample examples are presented in the form of Table 3.

The strength of the impact of individual personal factors is indicated by the number of other factors they are positively associated with (there are positive relationships between them). Table 4 lists the node levels that reflect this attribute. The higher the level of the node of the system, the greater its impact on other elements of the system. 
Figure 5.

A set of factors shaping the profile of social readiness to conduct operational activities in the face of hazards to societal safety

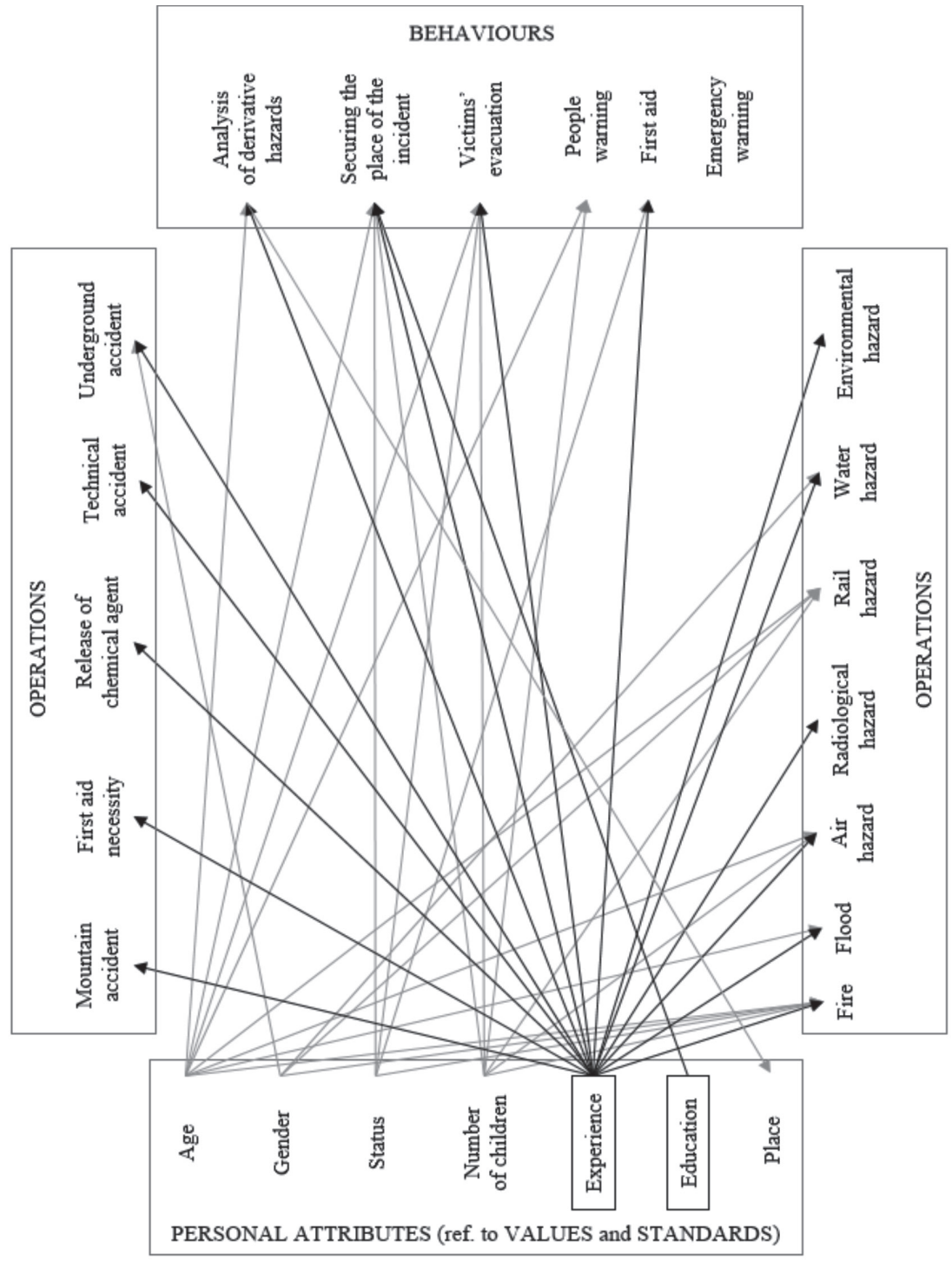

Source: own elaboration. 
Table 3.

Examples of possibilities of managing factors shaping the profile of social readiness to conduct operational activities in the face of natural and technical disasters

\begin{tabular}{|c|c|c|}
\hline $\begin{array}{l}\text { Name of } \\
\text { factor }\end{array}$ & $\begin{array}{l}\text { Phases of universal safety } \\
\text { management }\end{array}$ & $\begin{array}{c}\text { Impact } \\
\text { (possibilities to manage a factor) }\end{array}$ \\
\hline Age & $\begin{array}{c}\text { Prevention } \\
\text { Preparation } \\
\text { Emergency response } \\
\text { Reconstruction and } \\
\text { recovery }\end{array}$ & $\begin{array}{l}\text { Use of elderly people to initiate activities whose } \\
\text { effectiveness can be conditioned by life experi- } \\
\text { ence }\end{array}$ \\
\hline Gender & Emergency response & $\begin{array}{l}\text { Selection of men for rescue support requiring } \\
\text { considerable physical effort }\end{array}$ \\
\hline Status & $\begin{array}{l}\text { Preparation } \\
\text { Emergency response } \\
\text { Reconstruction and } \\
\text { recovery }\end{array}$ & $\begin{array}{l}\text { Use of people with a relatively high status for } \\
\text { planning rescue operations }\end{array}$ \\
\hline $\begin{array}{l}\text { Number of } \\
\text { children }\end{array}$ & Preparation & $\begin{array}{c}\text { Inclusion of people with a relatively large } \\
\text { number of children to define requirements of } \\
\text { preparing the community for hazards }\end{array}$ \\
\hline Experience & $\begin{array}{c}\text { Prevention } \\
\text { Preparation } \\
\text { Emergency response } \\
\text { Reconstruction and } \\
\text { recovery }\end{array}$ & $\begin{array}{l}\text { Creating opportunities to acquire experience } \\
\text { related to prevention, preparation, response and } \\
\text { reconstruction after hazards occur }\end{array}$ \\
\hline Education & $\begin{array}{l}\text { Prevention } \\
\text { Preparation }\end{array}$ & $\begin{array}{l}\text { Including key information for societal safety at } \\
\text { all stages of education and professional develop- } \\
\text { ment }\end{array}$ \\
\hline Place & $\begin{array}{c}\text { Prevention } \\
\text { Preparation } \\
\text { Emergency response } \\
\text { Reconstruction and } \\
\text { recovery }\end{array}$ & $\begin{array}{l}\text { Involvement of people from smaller towns to } \\
\text { analyse secondary hazards at all stages of safety } \\
\text { management }\end{array}$ \\
\hline
\end{tabular}

Source: own elaboration. 
Table 4.

\section{Levels of nodes}

\begin{tabular}{|c|c|c|c|}
\hline \multirow{2}{*}{ Factor } & \multicolumn{3}{|c|}{ Node level } \\
\cline { 2 - 4 } & in relation to behaviour & in relation to actions & Overall \\
\hline Age & 4 & 4 & 8 \\
\hline Gender & 0 & 4 & 4 \\
\hline Status & 3 & 1 & 4 \\
\hline $\begin{array}{c}\text { Number of } \\
\text { children }\end{array}$ & 3 & 3 & 6 \\
\hline Experience & 4 & 11 & 15 \\
\hline Education & 1 & 0 & 1 \\
\hline
\end{tabular}

Source: own elaboratiown.

Analyzing research results, it turned out that previous rescue experience has the strongest impact on social readiness in the context under consideration. This factor is characterized by the highest node level of all the nodes of the entire system - a number that is twice as high as the next personal factor, which is the second most important factor, namely age (indirectly related to life experiences). It is also worth mentioning that the fact of having children is associated with increased analytical potential in relation to the situational conditions of societal safety hazards.

\section{WAYS TO SHAPE THE CULTURE OF SOCIETAL SAFETY}

Information about the system and the strength of factors influencing the profile of social readiness, as well as the management options related thereto, was adopted as the basis for formulating specific ways of shaping the culture of societal safety.

According to the adopted methodology, attention was focused only on personal factors related to each other by statistically significant relationships. Their layout is shown in Figure 5. Then, the appropriate catalogue was verified in terms of which of the personal factors are managed by societal safety entities from the perspective of shaping the culture of societal safety and which are not. In this context, the impact was only visible on previous rescue experiences and education (the relationship is marked by black arrows in Figure 5). 
Importantly, both directions of this impact can be interrelated by, for instance, shaping experiences specifically in education processes.

Turning to the main part of the methodology, two cognitive perspectives referring directly to the Cieslarczyk model were taken into account in designing ways to shape the safety culture. These are behaviours and actions. Through their prism, the design process was carried out. The correct result is presented in Table 5.

Table 5.

\section{Ways to shape the culture of universal safety}

\begin{tabular}{|c|c|c|}
\hline Factor & $\begin{array}{l}\text { Element of the } \\
\text { Cieslarczyk } \\
\text { model }\end{array}$ & Ways to shape the culture of societal safety \\
\hline \multirow{4}{*}{ Experience } & \multirow{2}{*}{ Behaviours } & $\begin{array}{l}\text { Strengthening experiences regarding the analysis of } \\
\text { secondary hazards, securing the place of accident, } \\
\text { evacuation of victims and providing first aid }\end{array}$ \\
\hline & & $\begin{array}{l}\text { Providing opportunities to acquire experience regarding } \\
\text { warning the citizens and warning services }\end{array}$ \\
\hline & \multirow[t]{2}{*}{ Actions } & $\begin{array}{l}\text { Strengthening experience related to mountain accidents, } \\
\text { the need for first aid, the release of a dangerous chemical } \\
\text { agent, a technical accident, an underground accident, } \\
\text { environmental hazards, water hazards, radiological } \\
\text { hazards, aviation hazards, floods and fires }\end{array}$ \\
\hline & & $\begin{array}{l}\text { Providing opportunities to gain experience on rail } \\
\text { transport hazards }\end{array}$ \\
\hline \multirow{3}{*}{ Education } & \multirow[b]{2}{*}{ Behaviours } & $\begin{array}{l}\text { Strengthening educational processes related to securing } \\
\text { the place of incident }\end{array}$ \\
\hline & & $\begin{array}{l}\text { Development of educational processes related to the } \\
\text { analysis of secondary hazards, evacuation of victims, } \\
\text { warning the citizens, warning services and providing } \\
\text { first aid }\end{array}$ \\
\hline & Actions & $\begin{array}{l}\text { Development of educational processes that take into } \\
\text { account knowledge, skills and social competences } \\
\text { regarding all types of rescue operations }\end{array}$ \\
\hline
\end{tabular}

Source: own elaboration. 
The presented methods are characterized by a relatively high level of generality, so they are relatively universal. Within them, specific actions can be designed to increase the level of culture of societal safety, including (Warszawska \& Kraslawski, 2016):

- improving the flow of information between entities engaged in activities related to ensuring societal safety,

- building awareness of threats and other safety aspects in the face of natural disasters,

- acquiring knowledge and developing practical skills in dealing with these hazards,

- involving representatives of various groups in societal safety management processes,

- permanent monitoring and control of the effectiveness of raising the level of societal safety culture.

It is worth emphasizing that each of the actions listed above can be implemented within the methods described in Table 5. The implementation should be adapted to the conditions of societal safety in the area under consideration, depending on whether it is a local, regional, country or the international arena. The first priority should be to focus on ways and activities that correspond to strengthening or building experiences. More importantly, ways and activities which combine issues of experience and education may turn out to be the most valuable. Their mutual, synergistic impact may be reflected in the high efficiency of raising the level of culture of societal safety based on the social readiness profile. 


\section{Conclusion}

The article defines the system of factors determining the profile of social readiness. Not all relationships between them turned out to be statistically significant, and thus could be strengthened by shaping the right culture. Gaps have been noted within which consideration should be given to the appropriateness of designing desired ways and actions.

Elements of network analysis resulting from the concepts of Gomez, Probst and Ulrich provided valuable information on the relationships being the subject of research. The results of applying the adopted methodology emphasized the key role of strengthening and building a practical sphere of experience, supplemented by educational processes.

It should be emphasized that the conclusions were based on the analysis of factors influencing the conduct of operational (rescue) activities. Rescue seems to be the most visible field of societal safety and its conditions can be transferred directly to the conditions of the latter. However, this does not allow us to determine the full catalogue of factors that can affect the right culture and its level. Non-operational research is an interesting prospect for further scientific exploration, which open up to issues in the field of civil protection, civil defence or crisis management. 


\section{REFERENCES:}

Almklov, P., Antonsen, S., Bye, R. \& Øren, A. (2018). Organizational culture and societal safety: Collaborating across boundaries. Safety Science 110, pp. 89-99.

Almquist, Y. B., Ashir, S. \& Brännström, L. (online, v.1.0.1). A guide to quantitative methods. Stockholm: Stockholm University.

Aslam Saja, A. M., Goonetilleke, A., Teo, M. \& Ziyath, A. M. (2019). A critical review of social resilience assessment frameworks in disaster management. International Journal of Disaster Risk Reduction 36, 101096.

Aven, T., Boyesen, M., Njå, O., Olsen, K. H., Sandve, K. (2004). Societal Safety (Translated From Norwegian). Oslo: Universitetsforlaget.

Ayi, H-R. \& Hon, Ch-Y. (2018). Safety culture and safety compliance in academic laboratories: A Canadian perspective. Journal of Chemical Health and Safety 25, pp. 6-12.

Borel, J. (2015). Manage everything or anything? Possible ways towards generic emergency management capabilities. Journal of Disaster Research 10, pp. 246-251.

Choudhry, R. M., Fang, D. \& Mohamed, S. (2007). The nature of safety culture: A survey of the state-of-the-art. Safety Science 45, pp. 993-1012.

Cieslarczyk, M. (2009). Teoretyczne i metodologiczne podstawy badania problemów bezpieczeństwa i obronności państwa). Siedlce: Akademia Podlaska.

Cieślarczyk, M., Filipek, A., Świderski, A. W. \& Ważniewska, J. (2014). The essence of the security culture and its significance for an individual and social group. Kultura bezpieczeństwa 1-2, pp. 17-57.

Collins, A. E. (2013). Applications of the disaster risk reduction approach to migration influenced by environmental change. Environmental Science \& Policy 27, pp. 112-125.

Collins, A. E. (2018). Advancing the Disaster and Development Paradigm. International Journal of Disaster Risk Science 9 (4), pp. 486-495.

Cooper, M. D. (2000). Towards a model of safety culture. Safety Science 36, pp. 111-136.

Corrigan, S., Kay, A., Ryan, M., Ward, M. E. \& Brazil, B. (2018). Human factors and safety culture: Challenges and opportunities for the port environment. Safety Science 119 , pp. 252-265.

Cox, S. J. \& Cheyne, A. J. T. (2000). Assessing safety culture in offshore environments. Safety Science 34, pp. 111-129.

Crawford, E. G. C. \& Kift, R. L. (2018). Keeping track of railway safety and the mechanisms for risk. Safety Science 110, pp. 195-205.

Davies, G. F. \& Powell, W. W. (1992). Organization - environment relations. In: M., D. Dunnette \& L. M. Hough (Eds.). Handbook of Industrial and Organizational Psychology (pp. 315-365). Palo Alto: Consulting Psychologists Press.

DeJoy, D. M. (2005). Behavior change versus culture change: Divergent approaches to managing workplace safety. Safety Science 43, pp. 105-129. 
DeJoy, D. M., Smith, T. D., Dyal, M-A. (2017). Safety climate and firefighting: Focus group results. Journal of Safety Research 62, pp. 107-116.

Do Nascimento, C. S., Andrade, D. A. \& de Mesquita, R. N. (2017). Psychometric model for safety culture assessment in nuclear research facilities. Nuclear Engineering and Design 314, pp. 227-237.

Dollard, M. F., \& Bakker, A. B. (2010). Psychosocial safety climate as a precursor to conducive work environments, psychological health problems, and employee engagement. Journal of Occupational and Organizational Psychology 83, pp. 579-599.

Dong-Ping, F. \& Yang, Ch. (2005). Content, Performance, Evaluation and Construction of Construction Safety Culture. Construction Economics 2, pp. 41-45.

EM-DAT. (2019). OFDA/CRED International Disaster Database. Brussels: Université catholique de Louvain.

Fang, D. P., Chen, Y. \& Louisa, W. (2006). Safety climate in construction industry: a case study in Hong Kong. Journal of Construction Engineering and Management 132 , pp. 573-584.

Flage, R., Amundrud, Ø. \& Wiencke, H. S. (2014). Overall regional risk analysis offour Norwegian municipalities. In T. Nowakowski, M. Młyńczak, A. Jodejko-Pietruczuk, S. Werbińska-Wojciechowska (Eds.). Safety and Reliability: Methodology and Applications (pp. 21-34). London: Taylor \& Francis Group.

Fu, Y-K. \& Chan, T-L. (2014). A conceptual evaluation framework for organisational safety culture: An empirical study of Taipei Songshan Airport. Journal of Air Transport Management 34, pp. 101-108.

Gao, Y., Fan, Y., Wang, Y., Li, X. \& Pei, J. (2019). The mediating role of safety management practices in process safety culture in the Chinese oil industry. Journal of Loss Prevention in the Process Industries 57, pp. 223-230.

Geller, E. S. (1994). Ten principles for achieving a Total Safety Culture. Professional Safety, September, pp. 18-24.

Geller, E. S. (1997). The Psychology of Safety: How to Improve Behaviors and Attitudes on the Job. Florida: CRC Press, LLC.

Glendon, A. I. \& Stanton, N. A. (2000). Perspectives on safety culture. Safety Science $34,193-214$.

Goh, Y. M., Brown, H. \& Spickett, J. (2010). Applying systems thinking concepts in the analysis of major incidents and safety culture. Safety Science 48, pp. $302-309$.

Gomez, P. \& Probst, G. (1999). Die Praxis des ganzheitlichen Problemlösens. BernoStuttgart-Wien: Haupt Verlag.

Gromek, P. (2015). International Rescue Network in building Polish community resilience in response phase of people protection. In T. Zweglinski, P. Gromek, A. Predeckia \& M. Gikiewicz (Eds.). Awareness Raising, Bridging and Building Community Resilience (pp. 201-213). Warsaw-Karlstad: The Main School of Fire Service. 
Gromek, P. (2018a). W sieci ratownictwa. Warsaw: The Main School of Fire Service, Warsaw.

Gromek, P. (2018b). Istota bezpieczeństwa powszechnego w Polsce. Scientific Papers of the Main School of Fire Service, 68(4), pp. 161-176.

Grote, G. \& Kunzler, C. (2000). Diagnosis of safety culture in safety management audits. Safety Science 34, pp. 131-150.

Guldenmund, F. W. (2000). The nature of safety culture: a review of theory and research. Safety Science 34, pp. 215-257.

Hale, A. R. (2000). Culture's confusions. Safety Science 34, pp. 1-14.

Hale, A. R., Guldenmund, F.W., van Loenhout, P.L.C.H., \& Oh, J.I.H. (2010). Evaluating safety management and culture interventions to improve safety: Effective intervention strategies. Safety Science 48, pp. 1026-1035.

Hamra, J., Wigand, R., Hossain, L. \& Owen, Ch. (2017). Network effects on learning during emergency events. Knowledge Management Research \& Practice 12, 387-397.

Harvey, J., Erdos G., Bolam H., Cox, M. A., Kennedy, N. P. \& Gregory D. T. (2002). An Analysis of Safety Culture Attitude in a Highly Regulated Environment. Work \& Stress 16, pp. 18-36.

Haukelid, K. (2008). Theories of (safety) culture revisited - An anthropological approach. Safety Science 46, pp. 413-426.

He, A., Xu, S. \& Fu, G. (2012). Study on the Basic Problems of Safety Culture. Procedia Engineering 43, 245-249.

Hecker, N. \& Domres, B. D. (2018). The German emergency and disaster medicine and management system - history and present. Chinese Journal of Traumatology 21, pp. 64-72.

Hossain, L. \& Kuti, M. (2010). Disaster response preparedness coordination through social networks. Disasters 34, pp. 755-786.

Hossain, L., Hamra, J., Wigand, R.T. \& Carlsson, S. (2015). Exponential random graph modelling of emergency collaboration networks. Knowledge-Based Systems 77, pp. 68-79.

Høyland, S. A. (2018). Exploring and modeling the societal safety and societal security concepts - A systematic review, empirical study and key implications. Safety Science 110 , pp. 7-22.

Iqbal, H., Waheed, B., Haider, H., Tesfamariam, S. \& Sadiq, R. (2019). Mapping safety culture attributes with integritymanagement programto achieve assessment goals: A framework for oil and gas pipelines industry. Journal of Safety Research 68, pp. 59-69. Jingkai, L. (2012). Establishment of Emergency Management System Based on the Theory of Risk Management. Proceedia Engineering 32, pp. 108-112.

Jones, E. C. \& Faas, A.J. (Eds.). (2017). Social Network Analysis of Disaster Response, Recovery, and Adaptation. Oxford-Cambridge: Elsevier. 
Kasim, H., Hassan, Ch. R. Ch., Hamid, M.D., Emamia, S.D. \& Danaee, M. (2019). The relationship of safety climate factors, decision making attitude, risk control, and risk estimate in Malaysian radiation facilities. Safety Science 113, pp. 180-191.

Kennedy, R. \& Kirwan, B. (1998). Development of a hazard and operability-based method for identifying safety management vulnerabilities in high risk systems. Safety Science 30, pp. 249-274.

KG PSP (2021). Statistics of the National Firefighting Rescue System. Pozyskano (08.04.2021) z https://dane.gov.pl/pl/dataset/2080,statystyki-zdarzen-systemu-wspomagania-decyzji-pan.

Knight L. (Ed.). World disaster report (2009). Geneva: International Federation of Red Cross and Red Crescent Societies (IFRC).

Landau, S., Everitt, B. S. (2004). A Handbook of Statistical Analyses using SPSS. Boca Raton, London, New York, Washington: CRC Press.

Lassa, J. A. (2015). Post Disaster Governance, Complexity and Network Theory: Evidence from Aceh, Indonesia After the Indian Ocean Tsunami 2004. PLOS Currents Disasters 1, pp. 1-21.

Leonard, S. \& O'Donovan A. (2018). Measuring safety culture: Application of the Hospital Survey on Patient Safety Culture to radiation therapy departments worldwide. Practical Radiation Oncology 8, pp. e17 - e26.

Li, X. \& Zhao, X. (2019). Agent action diagram: Toward a model for emergency management system. Simulation Modelling Practice and Theory 94, pp. 66-99.

Liu, D., Wang, H., Qi, Ch., Zhao, P. \& Wang, J. (2016). Hierarchical task network-based emergency task planning with incomplete information, concurrency and uncertain duration. Knowledge-Based Systems 112, 67-79.

Madigan, M. L. Handbook of Emergency Management Concepts. A Step-by-Step Approach. Boca Raton - London - New York: CRC Press. Taylor \& Francis Group.

Maloney, W. F., Smith, G.R. (2003). Reciprocal determinism model of safety. Proceedings of Construction Research Congress March 19-21, Honolulu, Hawaii, USA.

Masys, A. J. (2017). Critical Infrastructure and Vulnerability: A Relational Analysis Through Actor Network Theory. In: A.J. Masys, Networks and Network Analysis for Defence and Security (pp. 265-280). York-Dordrecht-London: Springer, ChamHeidelberg-New.

Minhong, Z. (2001). Safety Culture Enhancement: Daya Bay NPP Safety Culture Indicators and Tentative Optimization. Chinese Journal of Nuclear Science and Engineering 12, pp. 95-99.

Neal, A. \& Griffin, M. A. (2002). Safety climate and safety behavior. Australian Journal of Management 27, pp. 67-75.

Neal, A., Griffith, M. A. \& Hart, P. M. (2000). The impact of organizational climate on safety climate and individual behavior. Safety Science 34, pp. 99-109. 
Nielsen, K. J. (2014). Improving safety culture through the health and safety organization: A case study. Journal of Safety Research 48, pp. 7-17.

Nyarugwe, S. P., Linnemann, A., Hofstede, G. J., Fogliano, V. \& Luning, P. A. (2016). Determinants for conducting food safety culture research. Trends in Food Science \& Technology 56, 77-87.

Odell, D. D., Quinn, Ch. M., Matulewicz, R. S., Johnson, J., Engelhardt, K. E., Stulberg, J.J., Yang, A.D., Holl, J.L. \& Bilimoria, K.Y. (2019). Association Between Hospital Safety Culture and Surgical Outcomes in a Statewide Surgical Quality Improvement Collaborative. Journal of the American College of Surgeons 229, pp. 175-183.

Olsen, O. E., Kruke, B. I. \& Hovden, J. (2007). Societal safety: concept, borders and dilemmas. Journal of Contingencies and Crisis Management 15(2), pp. 69-79.

Palen, L., Hiltz, S. R. \& Liu, S. B. (2007). Online forums supporting grassroots participation in emergency preparedness and response. Communications of the ACM 50(3), pp. 54-58.

Pidgeon, N. (1998). Safety culture: key theoretical issues. Work and Stress 12 (3), pp. 202-216.

Probst, G. \& Gomez, P. (1989). Vernetztes Denken, Unternehmen ganzheitlichen führen. Wiesbaden: Gabler Verlag.

Reason, J. (1997). Managing the Risks of Organizational Accidents. Aldershot: Ashgate.

Reiman, T. \& Rollenhagen, C. (2014). Does the concept of safety culture help or hinder systems thinking in safety? Accident Analysis and Prevention 68, pp. 5-15.

Richter, A. \& Koch, C. (2004). Integration, differentiation and ambiguity in safety cultures. Safety Science 42, pp. 703-722.

Roser, M. Natural Disasters. Pozyskano (08.04.2021) z https://ourworldindata.org/ natural-disasters.

Schein, E. H. (1992). Organizational Culture and Leadership. San Francisco: Jossey-Bass.

Schmidt, S. \& Galea, E. (Eds.) (2013). Behaviour - Security - Culture. Human behaviour in emergencies and disasters: A cross-cultural investigation. Lengerich-BerlinBremen-Miami-Riga-Viernheim-Wien-Zagreb: Pabst Science Publishers.

Shirali, G., Shekari, M. \& Angali, K. A. (2018). Assessing Reliability and Validity of an Instrument for Measuring Resilience Safety Culture in Sociotechnical Systems. Safety and Health at Work 9, pp. 296-307.

Stewart, J. M. (2002). Managing for World Class Safety. New York: John Wiley \& Sons.

Strauch, B. (2015). Can we examine safety culture in accident investigations, or should we? Safety Science 77, pp. 102-111.

Thomas, D. C., Au, K. \& Ravlin, E.C. (2003). Cultural variation and the psychological contract. Journal of Organizational Behavior 24, pp. 451-471.

Timmermans, Ch., Alhajyaseen, W., Reinolsmann, N. Nakamura, N. \& Suzuki, K. (2019). Traffic safety culture of professional drivers in the State of Qatar. IATSS Research 43(4), pp. 286-296. 
Urlich, H. \& Probst, G. (1990). Anleitung zum ganzheitlichen Denken und Handeln. Ein Brevier für Füh-rungskräfte. Bern-Stuttgart: Verlag Paul Haupt.

Varda, D., Forgette, R., Banks, D. \& Contractor, N. (2009). Social Network Methodology in the Study of Disasters: Issues and Insights Prompted by Post-Katrina Research. Population Research and Policy Review 28, pp. 11-29.

Vaughan, D. (1996). The Challenger Launch Decision: risky Technology, Culture, and Deviance at NASA. Chicago: University of Chicago Press.

Vecchio-Sadus, A. M. \& Griffiths, S. (2004). Marketing strategies for enhancing safety culture. Safety Science 42, pp. 601-619.

Vinodkumar, M. N. \& Bhasi, M. (2009). Safety climate factors and its relationship with accidents and personal attributes in the chemical industry. Safety Science 47, pp. 659-667.

Vogus, T. J., Cull, M. J., Hengelbrok, N.E., Modell, S.J. \& Epstein, R.A. (2016). Assessing safety culture in child welfare: Evidence from Tennessee. Children and Youth Services Review 65, pp. $94-103$.

Wachter, J. K. \& Yorio, P. L. (2014). A system of safety management practices and worker engagement for reducing and preventing accidents: An empirical and theoretical investigation. Accident Analysis and Prevention 68, pp. 117-130.

Wang, Ch-H. \& Liu, Y-J. (2012). Omnidirectional safety culture analysis and discussion for railway industry. Safety Science 50, pp. 1196-1204.

Wang, D., Qi, Ch. \& Wang, H. (2014). Improving emergency response collaboration and resource allocation by task network mapping and analysis. Safety Science 70, pp. 9-18.

Warszawska, K. \& Kraslawski, A. (2016). Method for quantitative assessment of safety culture. Journal of Loss Prevention in the Process Industries 42, pp. 27-34.

Wiegmann, D. A., Zhang, H., von Thaden, T. L., Sharma, G., \& Gibbons, A. M. (2004). Safety culture: An integrative review. International Journal of Aviation Psychology 14, pp. 117-134.

Wolanin, J. (2017). Common Societal Security Culture in the Baltic Sea Region: Basics and the Way Forward. Stockholm: Council of the Baltic Sea States (CBSS) Secretariat. Zohar, D. (2000). A Group-Level Model of Safety Climate: Testing the Effect of Group Climate on Microaccidents in Manufacturing Jobs. Journal of Applied Psychology 85 , pp. 587-596. 
